ISSN 1991-8631

Original Paper

http://indexmedicus.afro.who.int

\title{
Purification and partial characterization of laccase from Lachnocladium sp.
}

\author{
P. A. WUYEP ${ }^{1}$, O. N. UME ${ }^{2}$, M. T. BAKARE-ODUNOLA ${ }^{2 *}$, A. J. NOK ${ }^{3,}$ \\ H. M. INUWA ${ }^{3}$ and N. B. AFOLABI-BALOGUN ${ }^{4}$ \\ ${ }^{1}$ Department of Biological Sciences, Ahmadu Bello University, Zaria, Nigeria. \\ ${ }^{2}$ Department of Pharmaceutical and Medicinal Chemistry, Ahmadu Bello University, Zaria, Nigeria. \\ ${ }^{3}$ Department of Biochemistry, Ahmadu Bello University, Zaria, Nigeria. \\ ${ }^{4}$ Center for Biotechnology Research and Traininig. Ahmadu Bello University, Zaria, Nigeria. \\ *Corresponding author, E-mail: mojitaibat@yahoo.com; Tel.:+2348035896043
}

\begin{abstract}
Laccase, a multicopper oxidase that catalyzes the oxidation of various aromatics, particularly phenolic substrates, e.g. hydroquinones guaiacol, 2,6-dimethoxyphenol or phenylene diamine, was purified and partially characterised from culture filtrates of a white rot fungus, Lachnocladium sp. This enzyme was purified by anion exchange and gel filtration chromatography. Laccase activity was determined using ABTS (2, 2'-azinobis-(3-ethylbenzthiazoline)-6-sulphonic acid) substrate. The culture filtrate had maximum laccase activity of $1.62 \mathrm{U} / \mathrm{ml}$ after 14 days of incubation. The purified laccase had an optimum temperature of $50{ }^{\circ} \mathrm{C}$ and its optimum $\mathrm{pH}$ was 6 for ABTS. The activity of this enzyme was enhanced by $\mathrm{Fe}^{2+}, \mathrm{Cu}^{2+}, \mathrm{Zn}^{2+}$ and $\mathrm{Ca}^{2+}$, and was inhibited by EDTA and sodium iodide. Laccase from Lachnocladium $\mathrm{sp}$. had a $\mathrm{K}_{\mathrm{m}}$ of $0.119 \mathrm{mM}$ and a $\mathrm{V}_{\max }$ of $0.313 \mathrm{U}$.

(C) 2012 International Formulae Group. All rights reserved.
\end{abstract}

Keywords: Lachnocladium sp., anion exchange chromatography, gel filtration chromatography, ABTS, DMP.

\section{INTRODUCTION}

Laccases (EC 1.10.3.2, p-diphenol: dioxygen oxidoreductase) belong to the multicopper oxidase family and catalyse the oxidation of various substrates with the simultaneous reduction of molecular oxygen to water (Alcalde, 2007). Laccase was first discovered by Yoshida in 1883 from the latex of Japanese lacquer tree (Rhus vernicifera) and are widely distributed in nature; in fungi, in plants, in some insects (Dittmer et al., 2004; Kramer et al., 2001) and in a few bacteria (Claus, 2003). Fungal laccases are considered as ideal green catalysts of great biotechnological impact due to their few requirements (they only require air, and they produce water as the only by-product) and their broad substrate specificity. Moreover, in the presence of small molecules known as redox mediators e.g. ABTS [2, 2'-azino-bis (3-ethylbenzthiazoline-6-sulfonate diammonium salt], laccases enhance their substrate specificity (Kunanmeni et al., 2007). These redox mediators lead to higher rates and yields of laccase substrates and act as diffusible electron carrier enabling the oxidation of high

(C) 2012 International Formulae Group. All rights reserved. DOI : http://dx.doi.org/10.4314/ijbcs.v6i2.20 
molecular weight biopolymers such as lignin, cellulose or starch (Kunamneni etal., 2007; Alcalde, 2007). In addition, very effective phenolic mediators, e.g. 2, 6-dimethoxyphenol (DMP) and succinic acid, enhance the transformation of non-natural laccase substrates like cypronidil to mixed oligomers through cross coupling (Kang et al., 2002). The application of fungal laccases for troublesome transformations (synthesis of antibiotics, anti-cancer drugs and hormone derivatives; digestion of lignocellulose to use as a carbon source; modifications of lignosulfonates for production of emulsifiers, surfactants and adhesives; synthesis of polymers with properties as redox films for bioelectronic devices and much more) has expanded the need for this biocatalyst (Kunanmeni et al., 2007). Also, different laccase applications require particular laccase with properties more suited for those applications. Laccases have been reviewed several times in recent years, generally with emphasis on narrow aspects. $\mathrm{Xu}$ (2005), Riva (2006) and Alcalde (2007); provide excellent summaries of the enzymology, electron transfer mechanisms of laccases and their industrial applications

In this work, we reported the purification and partial characterization of one of these laccases from a white-rot fungus Lachnocladium sp which is russuloid basidiomycete found mostly in the tropics and have a worldwide distribution of about 94 species (ZipcodeZoo.com).

\section{MATERIALS AND METHODS} Microorganism and culture conditions

The fungal strain, Lachnocladium sp. was obtained from Gumbi hill along Kaduna Kano expressway in Kaduna State, Nigeria. The fresh mycelia was dried and stored in a closed Petri dish at $0{ }^{\circ} \mathrm{C}$. This was cultured on malt extract agar medium at $28{ }^{\circ} \mathrm{C}$ for 5 days. For laccase production, mycelial plugs from the malt extract medium were used as innoculum for $25 \mathrm{ml}$ of liquid medium (prepared from ripe pineapple fruits), and was incubated at $32{ }^{\circ} \mathrm{C}$ for 14 days.

\section{Enzyme assays}

The filtered homogenate of the liquid culture was assayed for laccase activity using ABTS and DMP as substrates. ABTS and DMP were from Apollo Scientific Ltd, UK. DEAE Cellulose and Sephadex G-100 were obtained from Sigma Chemical Co. St. Louis USA. All other chemicals used in this investigation were of analytical grade and was used without further purification. The assay solutions contained $1 \mathrm{mM}$ DMP in Mcllvaine buffer ( $\mathrm{pH} 7.0$ ) and $0.4 \mathrm{mM}$ ABTS in $25 \mathrm{mM}$ sodium acetate buffer ( $\mathrm{pH}$ 4.5) for DMP and ABTS substrates respectively. In the case of ABTS, the reaction was monitored by measuring the absorbance at $420 \mathrm{~nm}\left(\varepsilon_{\max }=\right.$ $3.6 \times 10^{4} \mathrm{M}^{-1} \mathrm{~cm}^{-1}$ ) (Bourbonnais and Paice, 1990). For DMP, the reaction was monitored by measuring the absorbance at $477 \mathrm{~nm}$ $\left(\varepsilon_{\max } 14.8 \times 10^{3} \mathrm{M}^{-1} \mathrm{~cm}^{-1}\right)$ (Palmieri et al., 1997). Helios Zeta UV-VIS Spectrophotometer (Thermo Scientific Inc.) was used for absorbance measurement. One unit of enzyme activity was defined as the amount of enzyme required for the oxidation of $1 \mathrm{~mol}$ of the substrate per minute in the reaction mixtures. The Specific activity, Purification fold and the Percentage yield of the enzyme were estimated from the following formulae:

$$
\begin{aligned}
& \text { Specific activity }=\frac{\text { Activity }(\mathrm{U} / \mathrm{ml})}{\mathrm{mg} \text { protein }} \\
& \text { Purification fold }=\frac{\text { SAEP }}{\text { SACE }} \\
& \text { SAEP }=\text { Specific activity of enzyme after a purification } \\
& \text { step. } \\
& \text { SACE }=\text { Specific activity of the crude enzyme. } \\
& \text { Percentage yield }=\frac{\text { TAEP }}{\text { TAEC }} \times 100 \\
& \text { TAEAP }=\text { Total amount of enzyme after a purification } \\
& \text { step } \\
& \text { TAECE }=\text { Total amount of enzyme in the crude extract }
\end{aligned}
$$




\section{Purification of laccase}

The liquid culture homogenate was used for the purification of enzyme after filtration through Whatman No. 1 filter paper. The filtrate was loaded onto a Sephadex G100 column pre-equilibrated with $25 \mathrm{mM}$ sodium acetate buffer, $\mathrm{pH} 4.5$. The enzyme was eluted with the same buffer at a flow rate of $1 \mathrm{ml} / \mathrm{min}$ and $5 \mathrm{ml}$ fractions were collected. These were assayed for enzyme activity and protein concentration. Protein concentration was determined using Layne's spectrophotometric method (Layne, 1957). The fractions with high enzyme activity were pooled, dialyzed and further purified with DEAE cellulose anion exchange chromatography. The DEAE Cellulose column was pre-equilibrated with $25 \mathrm{mM}$ sodium acetate buffer and the enzyme was eluted with a linear concentration gradient of $0-0.5 \mathrm{M} \mathrm{NaCl}$ in the same buffer at a flow rate of $1 \mathrm{ml} / \mathrm{min}$ and $5 \mathrm{ml}$ fractions were collected. The fractions containing high laccase activity were collected and pulled together.

\section{Characterization of laccase pH and temperature optimum}

The effect of temperature on laccase activity was determined following the laccasecatalyzed oxidation of $1 \mathrm{mM}$ DMP at temperatures ranging from $25-100{ }^{\circ} \mathrm{C}$ in Mcllvaine buffer ( $\mathrm{pH}$ 7.0).

The $\mathrm{pH}$-dependence of the laccase activity was examined at room temperature $\left(25^{\circ} \mathrm{C}\right)$ in the $\mathrm{pH}$ range of 3-9.0 using DMP and ABTS as substrates.

\section{Kinetics and inhibition studies}

The kinetics studies were performed using different concentrations (0.1-1.0 mM) of ABTS in $25 \mathrm{mM}$ acetate buffer $(\mathrm{pH} 4.5)$. These were incubated with $0.5 \mathrm{ml}$ of the enzyme at $37{ }^{\circ} \mathrm{C}$ for $10 \mathrm{mins}$ and the activity was determined spectrophotometrically. The data obtained were used for Lineweaver-Burk plot from which the $\mathrm{K}_{\mathrm{m}}$ and $\mathrm{V}_{\max }$ were determined.

The inhibitory effects of EDTA and sodium iodide on the activity of the enzyme were studied. The potential inhibitors, EDTA and sodium iodide at concentrations of 25, 50, 75 and $100 \mathrm{mM}$ each were mixed with ABTS and $0.08 \mathrm{ml}$ of the purified enzyme. All assays were performed in duplicate.

\section{Effects of incubation time and divalent cations}

Laccase from Lachnocladium sp. was studied for the effect of incubation time on its activity. The enzyme was incubated with ABTS at $37{ }^{\circ} \mathrm{C}$ and the activity was monitored at ten minutes interval for 60 minutes.

The effect of some divalent cations; $\mathrm{Zn}^{2+}, \mathrm{Ca}^{2+}, \mathrm{Fe}^{2+}$ and $\mathrm{Cu}^{2+}$ on the enzyme was also studied using ABTS as substrate. The substrate, $0.05 \mathrm{ml}$ of the enzyme and $0.2 \mathrm{ml}$ of $25 \mathrm{mM}$ of each divalent cation were incubated in different test tubes and activity was determined as described earlier.

\section{RESULTS}

The elution profile of the gel filtration chromatography and anion exchange chromatography of the enzyme revealed multiple distinct activity peaks Figures 1, 2 and 3. The purification chart for the purification of laccase from the culture filtrate of Lachnocladium sp. is shown in Table 1. Gel filtration chromatography gave the highest specificity $(34.33 \mathrm{U} / \mathrm{mg})$, purification fold (78.3) and percentage yield (27\%).

Laccase showed activity over a wide $\mathrm{pH}$ range between $\mathrm{pH} 3$ and 7 . The optimum $\mathrm{pH}$ of the enzyme for DMP was 7 (Figure 4) while that of ABTS was 6 (Figure 5). The dependence of laccase on $\mathrm{pH}$ rendered a bellshaped profile as can be seen with both ABTS and DMP.

The optimum temperature for laccase from lachnocladium sp. for DMP oxidation was $50{ }^{\circ} \mathrm{C}$. The enzyme is active over a wide 
temperature range. Significant activity was detected as low as $25{ }^{\circ} \mathrm{C}$ and $60 \%$ of activity was maintained as high as $90{ }^{\circ} \mathrm{C}$ (Figure 6).

The inhibition by $\mathrm{NaI}$ was only observed at higher concentration (above 75
$\mathrm{mM}$ ) while that of EDTA was observed to increase as its concentration increases (Figure 7); and the laccase activity decreased with longer incubation time (Figure 8).

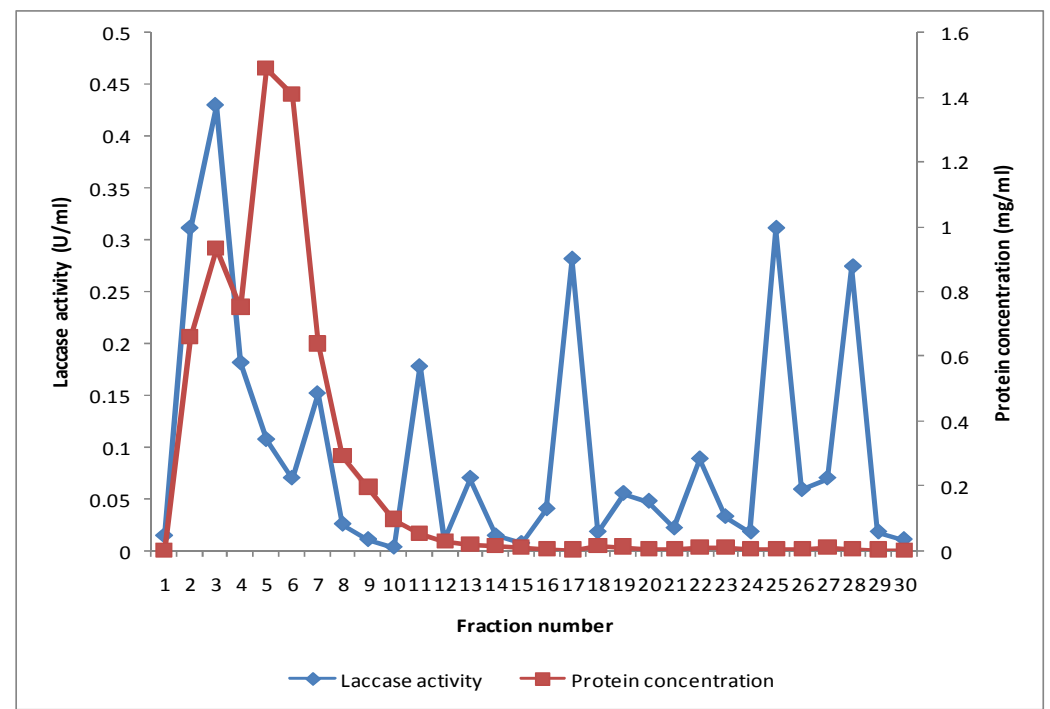

Figure 1: The elution profile of laccase on Sephadex G-100 gel filtration chromatography using ABTS as substrate.

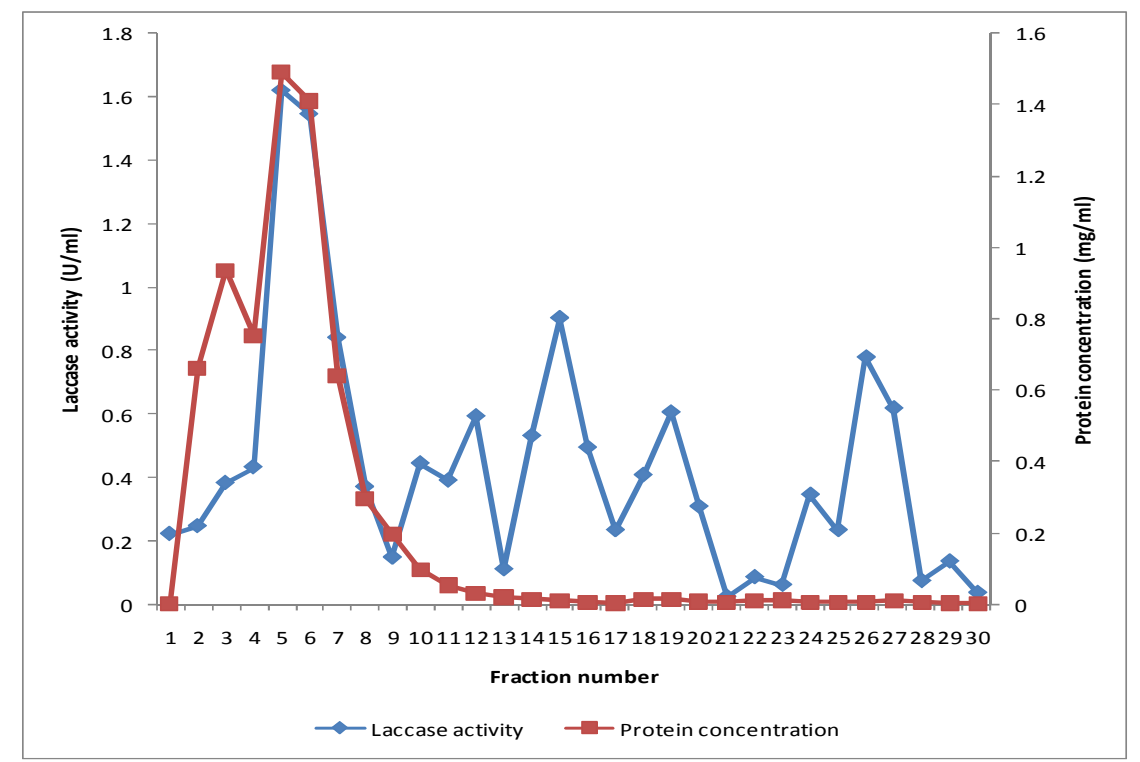

Figure 2: The elution profile of laccase on Sephadex G-100 gel filtration chromatography using DMP as substrate. 
P.A. WUYEP et al. /Int. J. Biol. Chem. Sci. 6(2): 782-791, 2012

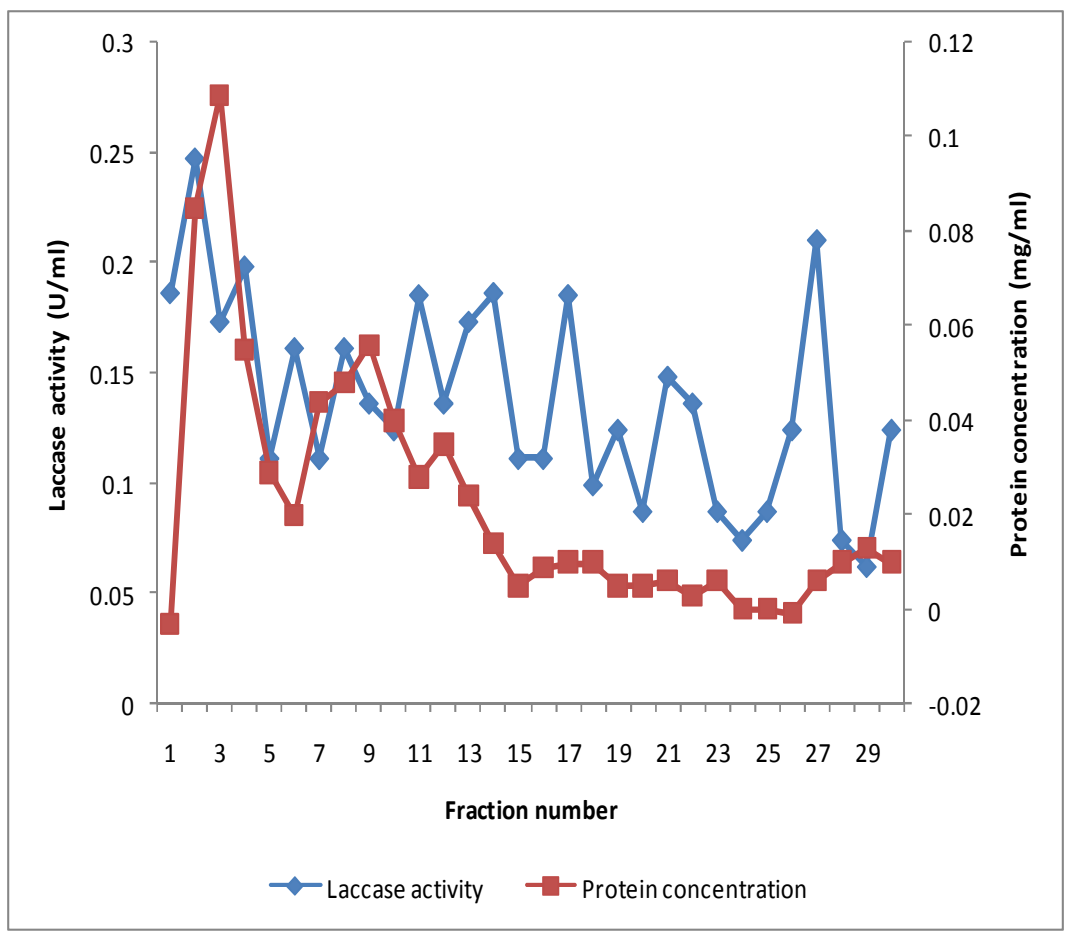

Figure 3: The elution profile of laccase on DEAE Cellulose anion exchange chromatography.

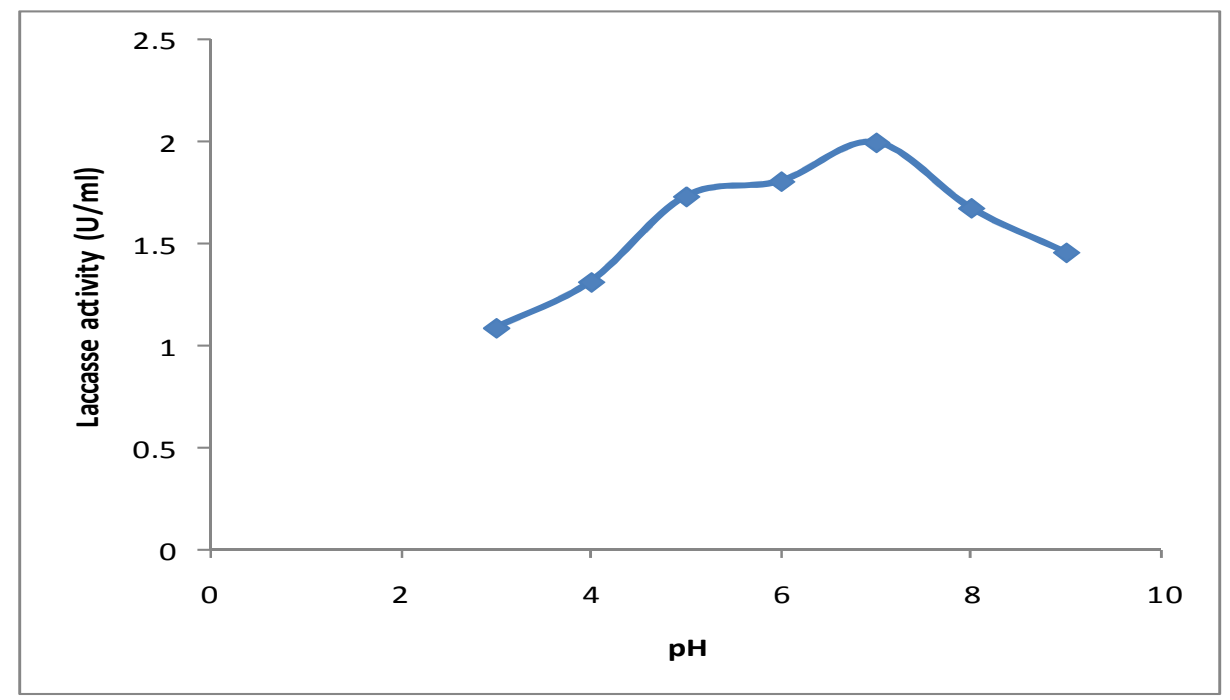

Figure 4: Effect of $\mathrm{pH}$ on laccase activity using DMP. 


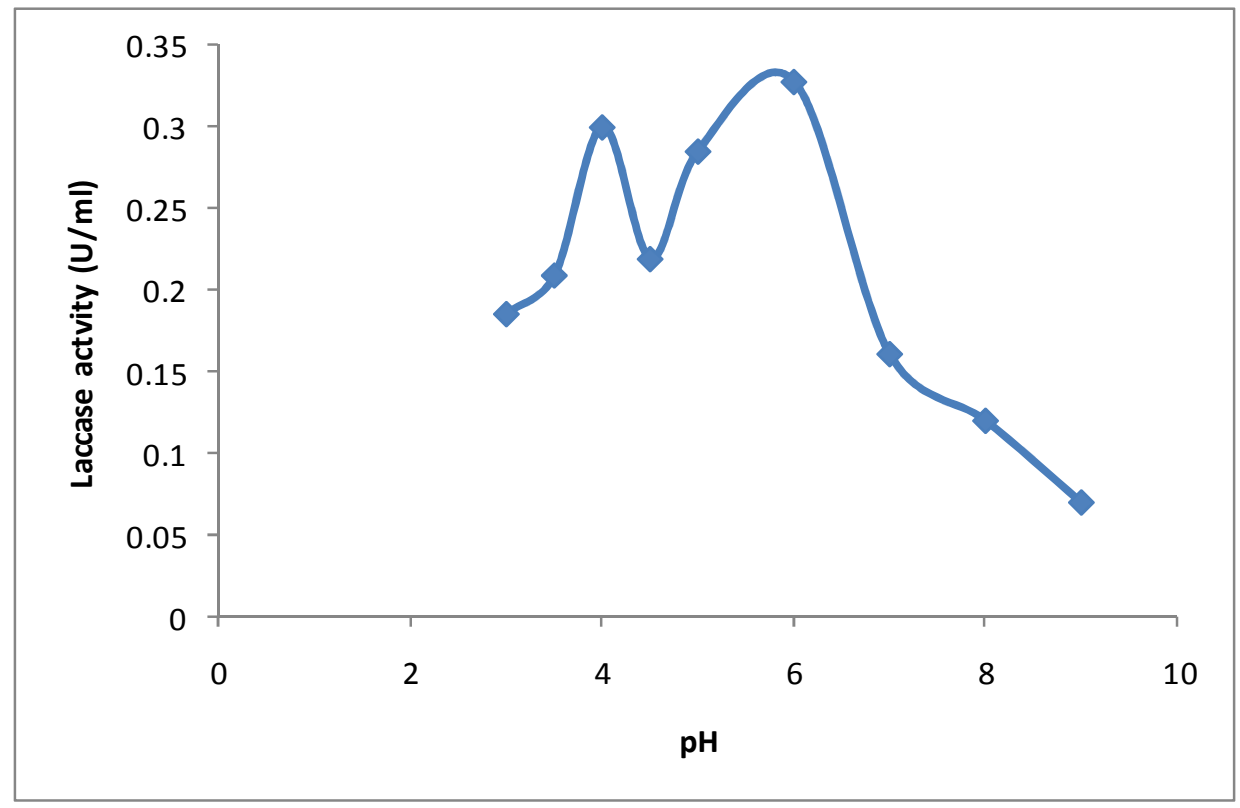

Figure 5: Effect of $\mathrm{pH}$ on using ABTS.

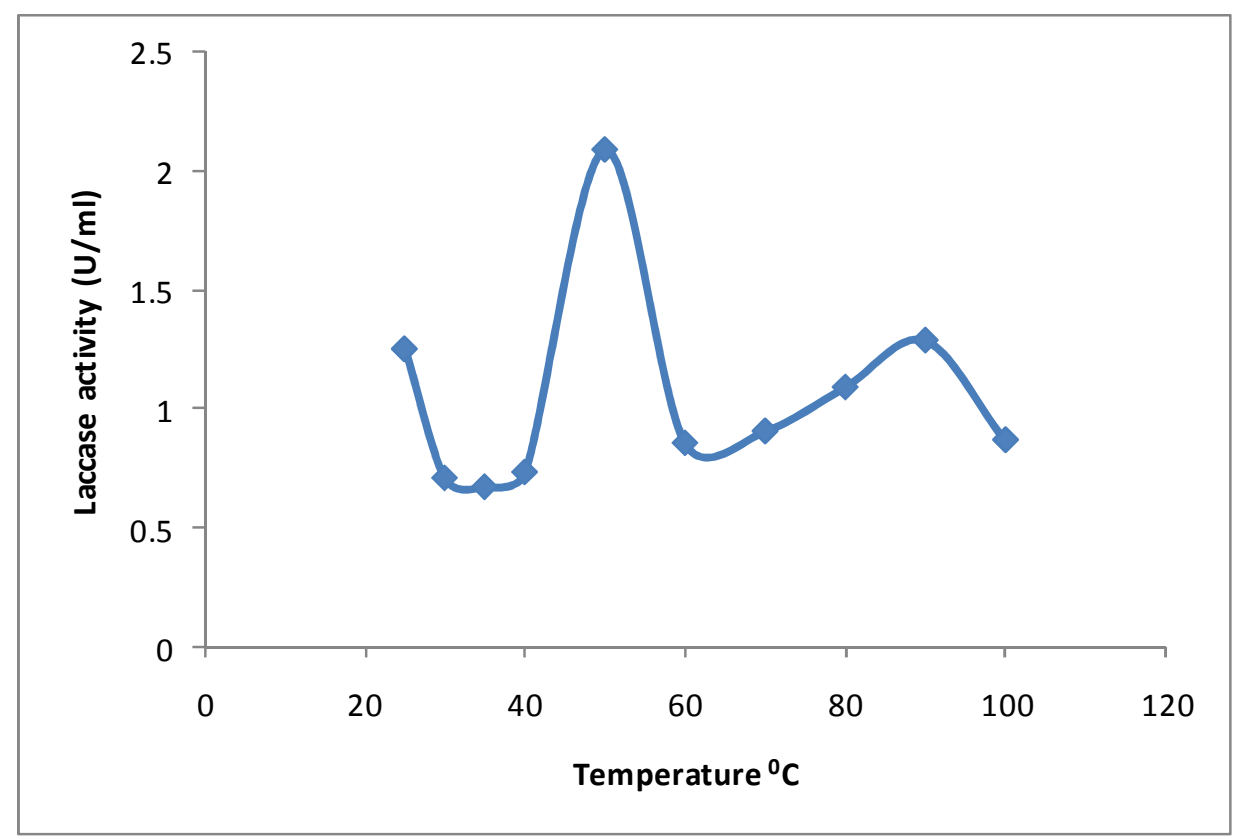

Figure 6: Effect of temperature on laccase activity for DMP oxidation. 


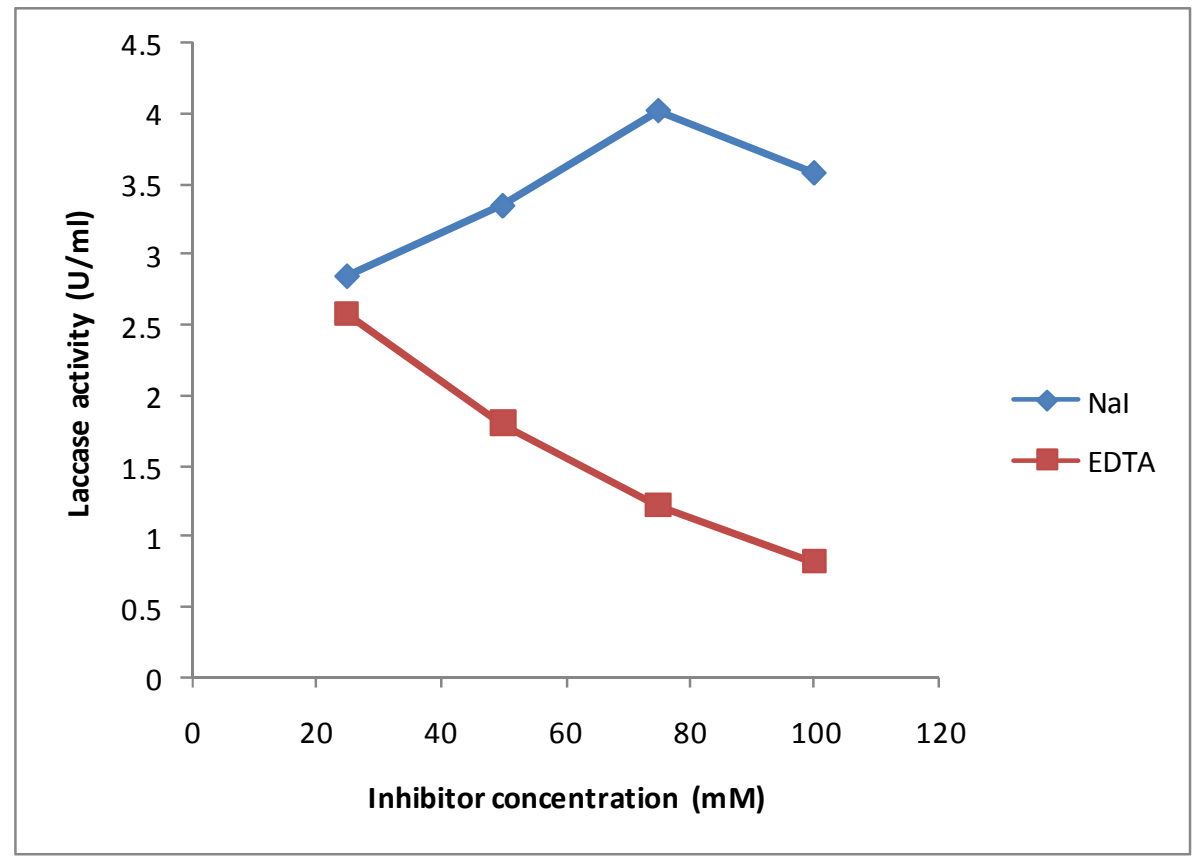

Figure 7: Effect of varying concentration of inhibitors on laccase activity.

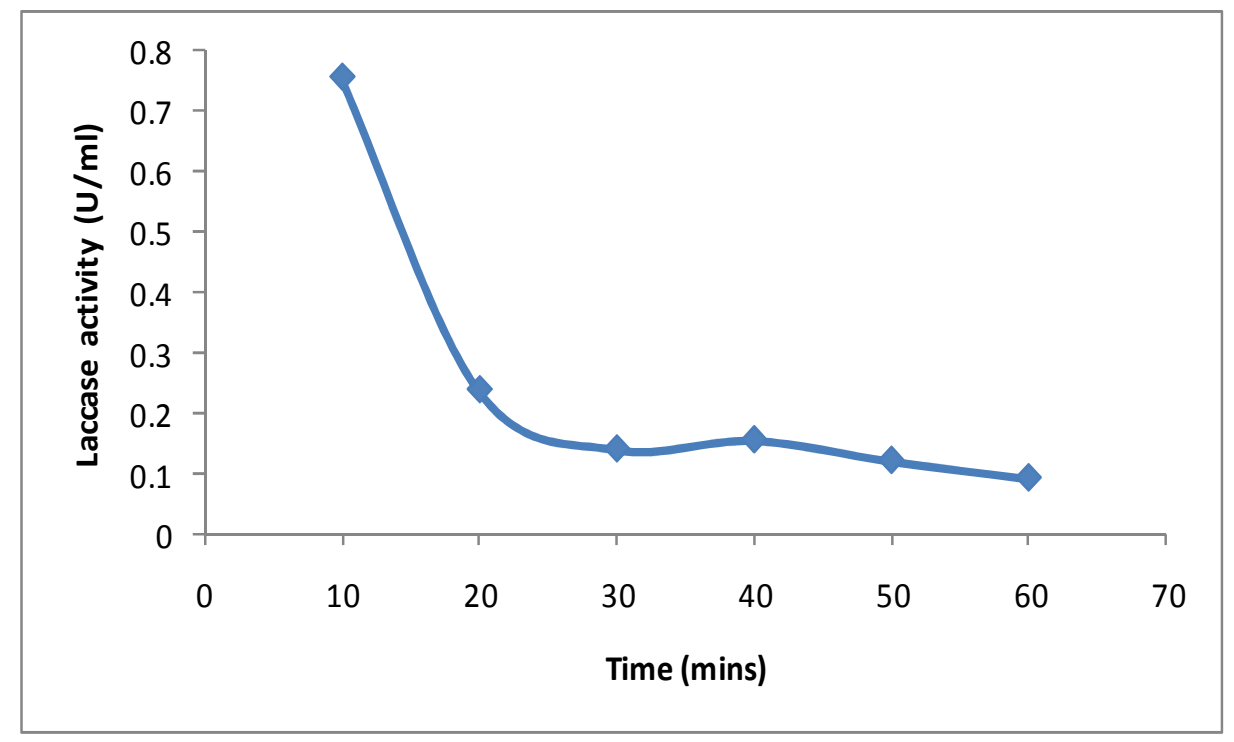

Figure 8: Effect of incubation time on laccase activity. 


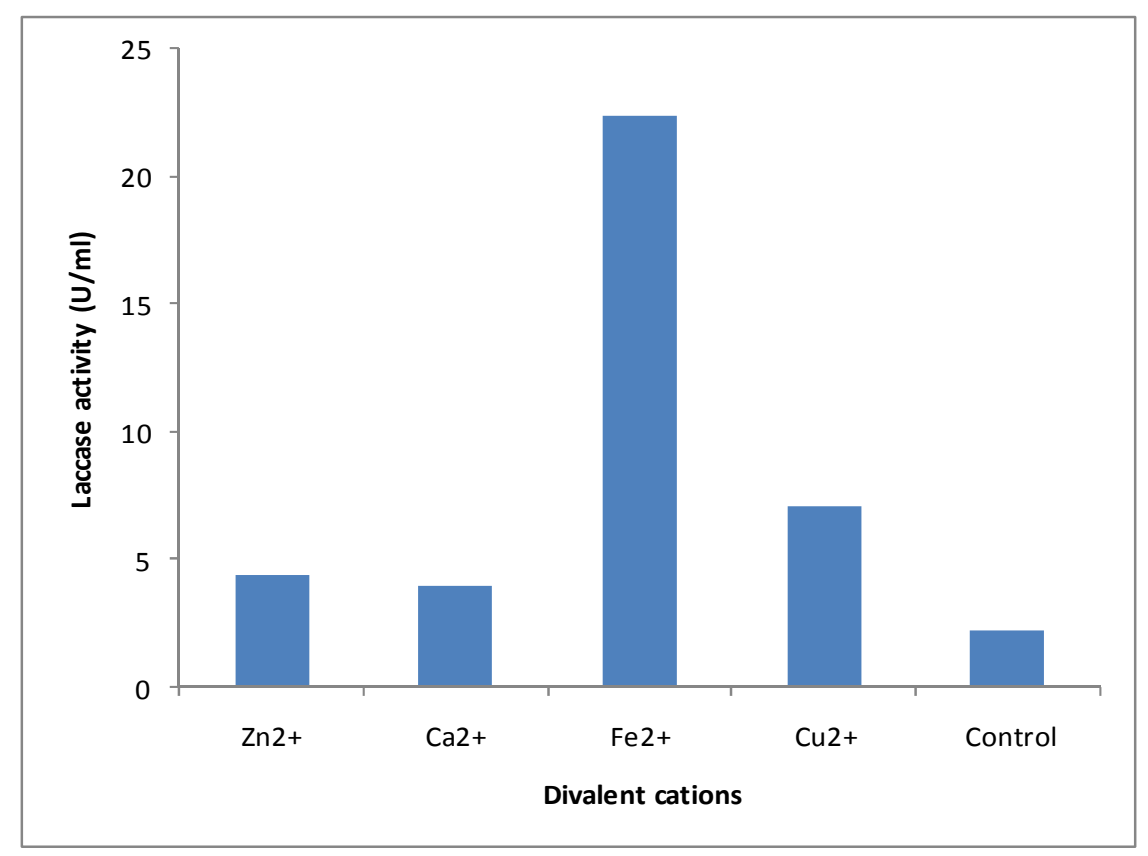

Figure 9: Effect of divalent cations on laccase activity.

Table 1: Purification chart of laccase from Lachnocladium sp.

\begin{tabular}{llllll}
\hline Purification Step & Protein $(\mathbf{m g})$ & $\begin{array}{l}\text { Total Activity } \\
(\mathbf{U} / \mathbf{m l})\end{array}$ & $\begin{array}{l}\text { Specific Activity } \\
(\mathbf{U} / \mathbf{m g})\end{array}$ & $\begin{array}{l}\text { Purification } \\
\text { Fold }\end{array}$ & $\begin{array}{l}\text { \% } \\
\text { Yield }\end{array}$ \\
\hline Crude enzyme & 2.5 & 1.11 & 0.44 & 1 & 100 \\
\hline $\begin{array}{l}\text { Gel filtration } \\
\text { (Sephadex G-100) }\end{array}$ & 0.201 & 0.30 & 34.33 & 78.3 & 27 \\
\hline $\begin{array}{l}\text { Anion exchange } \\
\text { (DEAE Cellulose) }\end{array}$ & 0.024 & 0.19 & 17.1 & 38.86 & 17 \\
\hline
\end{tabular}

\section{DISCUSSION}

\section{Purification of laccase}

Screening for oxidative enzymes or mediators involves the investigation of many samples, as there are many parameters involved. For this reason one usually relies on the use of inexpensive, rapid and sensitive testing methods (Ko et al., 2001). The screening strategy must aim to identify fungal strains and enzymes that will work under industrial conditions (Alcalde, 2007). Hence the fungal culture for the extraction of laccase in this study was cost effective. The fungal filtrate had a maximum laccase activity of $1.62 \mathrm{U} / \mathrm{ml}$ after 14 days of incubation. The multiple activity peaks of the enzyme suggested isozymes. This agrees with the report of Anastasia and Joan (2002); that fungal laccases often occur as multiple isozymes expressed under different cultivation 
condition. The purification chart for the purification of laccase indicated the fact that laccases are not specific for their substrate range, as it varies from one organism to another (Trovaslet et al., 2004).

\section{pH and Temperature optimum}

The bell-shaped $\mathrm{pH}$ profile was as a result of two opposing effects: the first effect is due to the redox potential difference between a reducing substrate (e.g. phenolic compound) and the type 1 copper center of laccase, where the substrates dock and electron transfer rate was favoured for phenolic substrates at a high $\mathrm{pH}$. The second effect was generated by the binding of a hydroxide anion to the type 2 / type 3 copper centres of laccase, which inhibited the binding of $\mathrm{O}_{2}$, the terminal electron acceptor, and therefore inhibited the activity at a higher $\mathrm{pH}$ because of the increased amount of $\mathrm{OH}^{-}$ions (Martínez-Alvarez et al., 2008).

Significant activity was detected as low as $25{ }^{\circ} \mathrm{C}$ and approximately $60 \%$ activity was maintained as high as $90{ }^{\circ} \mathrm{C}$; this is in agreement with the temperature profiles of laccase activity which usually do not differ from other extracellular ligninolytic enzymes with optima between $50{ }^{\circ} \mathrm{C}$ and $70{ }^{\circ} \mathrm{C}$ (Baldrian, 2006). However, few enzymes with optima below $35{ }^{\circ} \mathrm{C}$ have been described, e.g. the laccase from $G$. lucidum with the highest activity at $25{ }^{\circ} \mathrm{C}$ (Ko et al., 2001).

\section{Kinetic and inhibition studies}

The low $\mathrm{K}_{m}$ value of $0.119 \mathrm{mM}$ indicates high binding affinity of the enzyme for the substrate ABTS and the $\mathrm{V}_{\text {max }}(0.313 \mathrm{U})$ gave an indication of its efficiency with this substrate. EDTA was found to be more efficient in binding with the copper atoms when compared with NaI. EDTA had a high inhibitory effect towards this enzyme. EDTA exhibits metal chelating properties so could combine with the copper atoms in the laccase active site and reduce the affinity for the substrate.

\section{Effect of incubation time and divalent cations}

Enzymes are deactivated over a period of time even at moderate temperatures. The divalent cations tested $\left(\mathrm{Fe}^{2+}, \mathrm{Cu}^{2+}, \mathrm{Zn}^{2+}\right.$ and $\mathrm{Ca}^{2+}$ ), were found to be activators of laccase activity as shown in Figure 9. This implies that they were required as cofactors for laccase activity. Most enzymes need factors (cofactors) other than polypeptide molecules for full activity.

This study has successfully purified laccase from Lachnocladium sp. chromatographically and partially characterised the enzyme by ion exchange and gel filtration chromatography. The crude culture filtrate had a maximum laccase activity of $1.62 \mathrm{U} / \mathrm{ml}$ after 14 days of incubation. The laccase was purified chromatographically and partially characterized. Its optimum $\mathrm{pH}$ was found to be 7 for DMP and 6 for ABTS while the optimum temperature for its activity was 50 ${ }^{\circ} \mathrm{C}$. Future research will be focussed on molecular studies towards large-scale production of the recombinant enzyme for industrial applications.

\section{ACKNOWLEDGEMENTS}

The authors greatly appreciate the Ahmadu Bello University, Zaria Special Research Grant Unit for funding this work.

\section{REFERENCES}

Alcalde M. 2007. Laccase: biological functions, molecular structure and industrial applications. In Industrial Enzymes: Structure, Function and Applications. Springer: New York; 459474. 
Anastasia PL, Joan MH. 2002. Cloning, characterization, and transcription of three Laccase genes from Gaeumannomyces graminis var. tritici, the take-all fungus. Applied and Environ. Microb., 68(3): 1305-1311.

Baldrian P. 2006. Fungal laccases occurrence and properties. FEMS Microbiol. Rev., 30: 215-242.

Bourbonnais R, Paice MG. 1990. Demethylation and delignification of kraft pulp by Trametes versicolor laccase in the presence of ABTS. Appl. Microbial Biotechnol., 36: 823-827.

Claus H. 2003. Laccases and their occurrence in prokaryotes. Arch. Microbiol., 179: 145-150.

Dittmer NT, Suderman RJ, Jiang H, Zhu YC, Gorman MJ, Kramer KJ, Kanost MR. 2004. Characterization of cDNAs encoding putative laccase-like multicopper oxidases and developmental expression in the tobacco hornworm, Manduca sexta, and the malaria mosquito, Anopheles gambiae. Insect Biochem. Mol. Biol., 34: 29-41.

Garzillo MV, Calao MC, Caruso C, Caporale C, Celleti D, Buonocore V. 1998. Laccase from white-rot fungus Trametes trogii. Microbial Biotechnol., 49: 545-551.

Kang KH, Dec J, Park H, Bollag JM. 2002. Transformation of fungicide cypronidil by a laccase of Trametes villosa in the presence of phenolic mediators and humic acid. Water Res., 36(19): 49074915.

Ko EM, Leem E, Choi HT. 2001. Purification and characterization of laccase isozymes from the white-rot basidiomycete
Ganoderma lucidum. Appl. Microbiol. Biotechnol., 57: 98-102.

Kramer KJ, Kanost MR, Hopkins TL, Jing H, Zhu YC, Xhu R, Kerwin JL, Turecek F. 2001. Oxidative conjugation of catechols with proteins in insect skeletal systems. Tetrahedron, 57: 385-392.

Kunamneni A, Camarero S, Garcia-Burgos C, Plou FJ, Ballesteros A, Alcalde M. 2007. Engineering and applications of fungal laccases for organic synthesis. Enz. Microb. Tech., 40(4): 563-568.

Layne E. 1957. Spectrophotometric and turbidimetric methods for measuring proteins. Methods in Enzymolog., 3: 447455.

Martínez-Alvarez O, Montero P, GómezGuillén C. 2008. Evidence of an active laccase-like enzyme in deepwater pink shrimp (Parapenaeus longirostris). Food Chemistry, 108(2): 624-632.

Palmieri G, Giardina P, Bianco C, Scaloni A, Capasso A, Sannia G. 1997. A novel white laccase from Pleurotus ostreatus. J. Biol. Chem., 272(50): 31301-31307.

Riva S. 2006. Laccases: blue enzymes for green chemistry. Trends in Biotechnology, 24(5): 219-226.

Trovaslet M, Enaud E, Guiavarc'h Y, Corbisier A, Vanhulle S. 2007. Potential of a Pycnoporus sanguineus laccase in bioremediation of wastewater and kinetic activation in the presence of an anthraquinonic acid dye Enz. Microb. Tech., 41(3): 368-376.

Xu F. 2005. Applications of oxidoreductases: recent progress. Indust. Biotech., 1: 3845 . 